\title{
The "Greatest good for the greatest number": Is this a good land-use ethic? ${ }^{1}$
}

\author{
by Paul M. Wood, R.P.F. ${ }^{2}$
}

\begin{abstract}
Implicitly, the "'greatest good for the greatest number"' serves as the dominant land-use ethic of professional foresters, but is flawed for several reasons that are discussed in this paper. In effect, when foresters invoke this ethic when they recommend or make land-use decisions, they are "taking sides" politically in exactly those situations in which professionals are ethically required to be politically neutral. I suggest that this problem may have contributed to the profession's recent lack of public credibility, but it also represents an opportunity for the profession to enhance its credibility by designing and explicitly adopting a more appropriate land-use ethic.
\end{abstract}

\section{Résumé}

Les ingénieurs forestiers ont un principe d'éthique implicite quant à l'utilisation du territoire; c'est ' "le plus grand bien pour le plus grand nombre."' Ce principe a cependant plusieurs défauts qui sont discutés dans cet article. En effet, lorsque les ingénieurs forestiers invoquent ce principe, en recommandant ou prenant des décisions quant à l'utilisation du territoire, ils prennent position politiquement dans des situations qui justement nécessiteraient leur neutralité politique. Nous suggérons que ce problème peut avoir contribué au manque de crédibilité actuel face au public. Mais cela représente aussi pour la profession une opportunité d'améliorer sa crédibilité en élaborant et adoptant explicitement un meilleur principe d'éthique de l'utilisation du territoire.

\section{Introduction}

As foresters, we are often involved in land-use decisions. As professionals, we are also guided by ethical principles. An important question for both foresters and the public, therefore, is: What ethical principle guides foresters when they recommend or make land-use decisions?

For decades, foresters in North America have been struggling with the ethics of forest land-use. The central theme, however, has not changed. One author has suggested that "professional forestry has not changed its fundamental perceptions in more than 200 years" (Behan 1990: 12). There have been changes in emphasis, from economic efficiency to ecological integrity, for example, but the central land-use principle can still be stated in the words of Gifford Pinchot, the first chief forester of the U.S. Forest Service, who said that forests should be allocated on the basis of "the greatest good for the greatest number"' (Pinchot 1947) ${ }^{3}$.

In view of the fact that heated public controversies over the use of forest land have become commonplace, perhaps it is time to revisit this principle. In this paper I will argue that the forestry profession's ethical perspective pertaining to forest land-use may be part of the problem. It is possible that this principle is outmoded and may be hindering the profession's credibility with the public. However, by realigning its ethical perspective on land-use, opportunities are available for the profession to better serve society and to enhance its credibility.

The argument will take the following format: First, I will point out that the forestry profession, depending on the province or state, enjoys either a legally sanctioned monopoly within its self-defined sphere of expertise, or considerable de facto control over the same area of expertise. Second, I will draw attention to the fact that the profession has included within its sphere of expertise certain subjects with

\footnotetext{
${ }^{1}$ A previous version of this paper was presented at: Moral Philosophy in the Public Domain: An International Conference on Applied Ethics in Business, Medicine and Environmental Policy. Vancouver, B.C. 7-9 June 1990. ${ }^{2}$ Doctoral Candidate; Faculty of Forestry; University of British Columbia.
}

strong political content. Third, I will claim that the profession's ethical perspectives make it obligatory that foresters adhere to specific political positions. Finally, in combination with these empirical observations, I will make the normative claim that the profession has assumed responsibilities for a portion of the political agenda which should more appropriately be retained within the public domain.

In short, this paper discusses the appropriate distribution of decision-making powers between the forestry profession and the public and will suggest that a re-distribution of power back to the public is ethically justified, may help to alleviate controversy in forest land-use issues, and may help the profession to recover its credibility.

\section{The Role of Professions in Society}

It can be expected that in most professions there will be questions concerning what should be included within the substantive "decision-making space" of professional judgment as opposed to what should be regarded as political decisions to be made by the public's elected representatives.

Some decisions are clearly within the domain of professional judgment, whereas others are clearly within the public domain. For example, professional engineers may be retained to design a bridge for a city. Judgments concerning the safety of the bridge are within the engineers' "decision-space" and a large part of the reason for retaining professional engineers is to ensure that the bridge is safely designed. However, judgments concerning whether or not the city wants the bridge in the first place is a political decision. The engineers may help with this decision by pointing out likely consequences of alternative options, but the decision of whether or not to build the bridge ultimately rests with the public's elected representatives.

\footnotetext{
${ }^{3}$ Actually, "the greatest good for the greatest number" was originally made famous by British philosopher Jeremy Bentham in his book, "Introduction to the Principles of Morals and Legislation” (1789). Pinchot was probably aware of Bentham's work.
} 
For other decisions it is not clear who should be the appropriate decision-maker. Questions concerning which decisions should be included within a profession's sphere of expertise are not simply matters of legal interpretation; they are also ethical issues.

Since the function of professions is to serve basic social values (Bayles 1989: 12), one would expect society to define the ethically acceptable "decision space" for the professions. But professions, including those that have exclusive rights to practice as defined by statute (i.e. those that have a monopoly on specified actions and judgments), usually enjoy a high degree of autonomy. Not only are they self-regulating but they usually have considerable discretionary authority to define, by proclamation, their spheres of expertise (Bayles 1989: 11). In short, what should be included within the ethically acceptable "decision space" for a profession is often left for the profession to decide.

Professions have argued that "because of the intellectual training and judgment required for their practice, nonprofessionals are unable to evaluate their [professional] conduct properly" (Bayles 1989: 12). But herein lies a source of potential conflict:

The combined effects of these three features - serving basic social values, monopoly, and self-regulation - are central to the issue of the role of professions in a modern society. Monopoly and self-regulation, if exercised improperly, can be detrimental to society and the quality of human life . . Monopolies are created for the benefit of society, and if they do not serve society well, then they are not justified. (Bayles 1989: 12)

\section{The Forestry Profession}

In recent years the public's attention on forest land-use issues has been increasing, while at the same time the credibility of the forestry profession has been declining. Public criticism of the profession has prompted a recent president of the Association of B.C. Professional Foresters to state that "foresters are in jeopardy of losing their right to practise ..." (Zak 1989: 2).

Like other professionals, foresters have been trained to be technically competent in their chosen field and, in a number of provinces and states, have been granted the legally exclusive right to practise in exchange for their assurance of competent performance. In British Columbia, for example, the Foresters Act gives professional foresters exclusive. rights of practice (i.e. licensed practice), but the Act is worded to give the profession a degree of flexibility in defining its own sphere of expertise $e^{4}$. This is also true in the province of Quebec and a few of the American states. But even for those jurisdictions which do not grant statutory rights of practice to foresters, foresters usually have considerable de facto control over natural resources, and usually adhere to codes of ethics prescribed by forestry organizations with voluntary membership 5 .

\footnotetext{
${ }^{4}$ Pers. commun., R. Bronstein, R.P.F., Executive Director, Assoc. of B.C. Professional Foresters.

${ }^{5}$ The Canadian Institute of Forestry and the Society of American Foresters are two such organizations that have voluntary membership.
}

With considerable freedom to define for themselves what should be included within their sphere of expertise, professional foresters have grown accustomed to making certain decisions that have political content. In effect, they have assumed that they have the right to make certain political decisions on behalf of society, although they may not recognize that these decisions have political content. One author, for example, has expressed concern that the U.S. Congress is resolving issues that he feels should more appropriately be resolved by professional foresters (Madden 1990: 36). From a similar perspective, a recent president of the Association of British Columbia Professional Foresters has simply stated that "Forestry is an environmental and political issue - not a technical or scientific issue!"' (Zak 1989: 2). Certainly, the most contentious issues within the forestry profession are not technical, but political.

In order to help clarify the difference between technical and political decisions in forestry, it is useful to note the distinction between a land-use decision on the one hand and a management decision on the other. The first involves a decision about the purpose(s) for which an area of forest land will be used and the second involves a decision about how to manage for, or how to achieve, the designated purpose. In a liberal democracy it is axiomatic that decisions concerning the intended use (i.e. purpose) of public land should be made by the public's elected representatives, or their designates. Public land-use issues are also inherently political because they are debatable public issues involving competing interests among persons in society.

While it is true that major land-use decisions are usually made by political representatives, professional foresters routinely make land-use decisions regarding public land. For example, in British Columbia, provincial forests ${ }^{6}$ are designated by politicians. However, within these major areas, numerous land-use decisions are made by professional foresters. Whether or not an environmentally sensitive area is to be logged, for example, or whether or not an area of wildlife winter range is to be set aside - these are land-use decisions made by professional foresters on behalf of the public. In general it is professional foresters employed by the government that approve the final plans, thereby effectively making many land-use decisions. I understand this general procedure is also true in other provinces and states and in the U.S. National Forests. As one forester from the U.S. Forest Service in Washington, D.C. pointed out, "The most troublesome environmental debates of the recent past and foreseeable future center on how to allocate the few remaining untouched forested areas" (Ostby 1989: 31). He then goes on to suggest that it is the role of professional foresters to make these allocations.

There is nothing inherently wrong with this general procedure of government professionals making decisions with regard to public land. The elected representative who is ultimately responsible for these decisions simply cannot be personally involved in all the detailed land-use decisions that must be made. He or she must delegate this responsibility to government employees and for forest land-use decisions, professional foresters are usually the responsible designates.

\footnotetext{
${ }^{6}$ Large areas in British Columbia known as Tree Farm Licenses and Timber Supply Areas are similarly designated by political processes.
} 
It is at this point, however, that the ethical perspectives of foresters become important because foresters have obligations to conform to their professional codes of ethics when making these land-use decisions.

\section{The Foresters' Current Land-use Ethic}

As discussed above, the forestry profession has implicitly adopted "the greatest good for the greatest number" as a land-use ethic. However, as a professional ethic and as an environmental ethic, it is flawed for several reasons.

First, it conflicts with itself. Note that it is actually two principles. The "greatest good" portion is a principle of aggregation; it demands that the aggregate good be maximized. The "greatest number" portion is a principle of distribution; it demands that the good be maximally distributed. But these two principles can be in conflict with each other. It is impossible to maximize two competing goals at the same time and there is no means for determining how to trade-off utility ${ }^{7}$ maximization with maximal distribution. For landuse decisions, this means that the principle does not tell us whether to maximize society's utility, regardless of to whom it accrues, or whether to ensure that utility is distributed equally (i.e. maximally) among persons in society, regardless of whether or not utility is maximized. For forestry purposes, "the greatest good for the greatest number" is a principle that comes with a built-in land-use conflict.

The second flaw is in its implementation. In practice, foresters do give preference to one of these two competing principles; they emphasize the aggregation of utility over the just distribution of utility. For example, the code of ethics of the Association of British Columbia Professional Foresters explicitly states that the first responsibility of each professional forester is to improve the utility and value of forest resources to society and to prevent any reduction in their utility ${ }^{8}$. Similarly, the Society of American Foresters has emphasized that it is a duty of professional foresters to ensure that "the country's forests yield their fullest contribution to the economic and social welfare of the nation" (Banzhaf et al. 1985: 220). If these tenets could provide guidance for the just distribution of public resources, then there might be little cause to challenge them. But just distribution is not explicitly included and I do not believe that it is implicitly intended. In a drive to maximize the utility of all forest resources, foresters assume that somehow just distribution will be obtained inadvertently. This is the basis of the "trickle-down effect." But as one author has pointed out: "The most difficult moral conflicts, especially in social life, are conflicts between utility and justice"' (Raphael 1981: 47). In effect, the land-use ethic adopted by foresters claims that forest land should be allocated so as to maximize utility, regardless of to whom it accrues.

A third problem is the scale of application of this professional tenet. Although not as explicitly stated, many foresters have interpreted this emphasis on utility maximization to mean that each and every area of forest must be devoted to the highest possible use. Terms such as "multiple use" and "integrated forest management," are interpreted by many to mean not that there should be a mixture of various

\footnotetext{
"For the purpose of this discussion "good" and "utility" can be used interchangeably.

${ }^{8}$ See sections 1 (a) and 1 (c) of the code of ethics of the Association of B.C. Professional Foresters.
}

forest uses over a large area, but rather that each small area should be allocated to the use that will yield the maximum utility. The issue here is a matter of scale. If each and every portion of a forest is allocated simply on the basis of maximum utility, then the broad picture may suffer. For example, it may be necessary to forgo the logging of some timber in order to preserve a sufficiently large wilderness area. Overall, the public may benefit from this tradeoff. But if each small piece of forest is evaluated in isolation and out of context, and the utility maximization ethic is invoked, then many or most of the smaller areas may be logged and the opportunity to protect a large wilderness area will not be given due consideration. Foresters often make this mistake in British Columbia. They have frequently argued that a specific wilderness area should not be considered for preservation because, they claim, it would then be allocated to a "single use," not "multiple use." Notwithstanding the fact that wilderness preservation accommodates many forest uses including aesthetic appreciation, recreation, and the retention of biological diversity, the "single use" argument reveals a failure to look at land-use issues in context. This myopic concentration on utility maximization at the micro level is flawed because it represents a failure to maximize utility at a broader level. In effect, society's resources are wasted if the "greatest good" ethic is not applied at the appropriate scale.

Finally, as a professional and environmental ethic, "the greatest good for the greatest number" is flawed if the word "good"' is given a narrow interpretation meaning either economic benefits or social benefits that can be measured in terms of willingness to pay. Foresters in British Columbia, to their credit, have recognized a need to accommodate intangible and non-consumptive forest uses in land-use planning. But in a proposed "Land-use Strategy" the Association of B.C. Professional Foresters continues to take a cost-benefit approach to land allocations. This approach, once again, implies that each land-use decision should be allocated on the basis of maximum utility where utility is measured in terms of willingness to pay. In effect, this approach suggests that land and resources are appropriately allocated if they are distributed to those who are willing to pay the most. As has been frequently pointed out, this approach is naive; it oversimplifies the preferential and ethical values inherent in these political issues (Copp 1987; Dorcey 1986; Kelman 1980; Sagoff 1988).

These are several objections to the foresters' current landuse ethic. But it is important to recognize that overall, this ethic constitutes a political position. It suggests that land-use decisions ought to be made on the basis of utility maximization, regardless of the just distribution of benefits among persons in society. When applied to political issues, this position then becomes a political position. Public land-use issues are inherently political because they are debatable public issues involving competing interests among persons in society.

The critical issue, therefore, is the juxtaposition of the professional forester's assigned task of making decisions on these political land-use issues and his commitment to his professional obligations. The extent to which professional foresters conform to the "greatest good for the greatest number" ethic when making public land allocation decisions, is the extent to which the political process has been compromised. The foresters' land-use ethic commits them to 
making decisions that favour their predetermined concept of what is good despite the fact that in these political issues what is good is publicly debatable by definition. To some extent, therefore, the public's ability to influence public landuse decisions has been diverted and substituted with the political choice of one profession.

The key point here is that professional bodies, in the ethical standards they impose on their members, must demand technical and professional competence but must not ask for political alliance. Subtly but clearly, the "greatest good for the greatest number" is an ethic that demands political alliance.

Although to my knowledge this problem has not been explicitly stated before, it is reasonable to surmise that the public has been intuitively aware of this issue. It is likely that heated public controversies over forest land-use issues, involving polarized factions, have been at least partly fueled by the unrecornized and subtle political agenda of the forestry profession.

\section{Foundations for a Revised Foresters' Land-use Ethic}

The profession's attempts to articulate a forest land-use ethic will be frustrated if it continues to focus on confused concepts of utility maximization. Instead, this ethic must be articulated in terms of liberal democratic principles, whereby the concept of the "good"' is not predetermined, but is dependent on political debate.

In the context of a liberal democracy, the public retains the right to choose what is good and exercises this right through elected legislators or by way of various forms of direct public participation. Attempts to divert some of this power to the relatively autonomous forestry profession can be perceived as unjust and may exacerbate the public's lack of confidence in the profession.

There is an opportunity for the profession to avoid these pitfalls by identifying the political content that is inherent in the practice of forestry, and by re-designing an appropriate foresters' land-use ethic. The exact shape that this new ethic should take is a subject that needs thorough discussion among foresters and with the public. But this much is clear: under such an ethic it would be necessary for the profession to concede that when public values are relevant to forestry decisions, including all public land-use decisions, the public and its elected representatives know best. The legitimate role of the forester under such an ethic would be to support and assist the public's opportunities and ability to participate in these political decisions.

\section{References}

Banzhaf, W.H., A.F. Burns, and J. Vance. 1985. Ethics and forestry. J. For. April 1985.

Bayles, Michael D. 1989. Professional Ethics. (second edition) Wadsworth Publishing Co.

Behan, R.W. 1990. Multiresource Forest Management: A Paradigmatic Challenge to Professional Forestry. J. For. April 1990.

Copp, D. 1987. The Justice and Rationale of Cost-Benefit Analysis. Theory and Decision 23:65-87.

Dorcey, A.H.J. 1986. Bargaining in the governance of Pacific coastal resources: research and reform. Westwater Research Centre, University of B.C.

Kelman, S. 1980. Cost-benefits analysis and environmental, safety, and health regulation: ethical and philosophical considerations. In D. Swartzman, R.A. Liroff, and K.C. Crocke (eds.) Cost-benefit analysis and environmental regulations: politics, ethics and methods. The Conservation Foundation, Washington, D.C.

Madden, R.B. 1990. The Forestry Challenge of the Nineties. J. For. January 1990.

Ostby, D. 1989. A Reviewer Comments [on the immediately preceding article by J.E. Coufal: Forestry: In Evolution or Revolution.] J. For. May 1989.

Pinchot, G. 1947. Breaking New Ground. University of Washington Press.

Raphael, D.D. 1981. Moral Philosophy. Oxford University Press. Sagoff, M. 1988. Some Problems with Environmental Economics. Environmental Ethics. Vol. 10 (Spring 1988).

Zak, B. 1989. The President's Corner. The B.C. Professional Forester. October 1989.

\section{Change of Address}

Date

Surname first - no titles

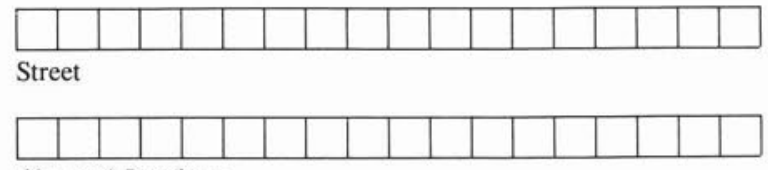

City and Province

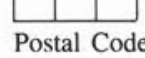

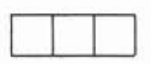
Section

$$
\text { D }
$$

\section{Changement d'adresse}

Date Section

Prénom en avant - pas de titres

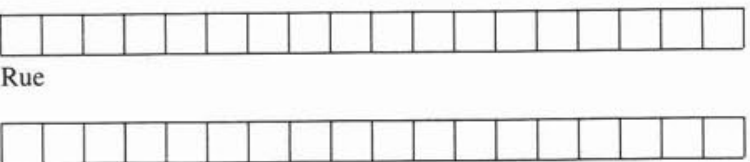

Ville et Province

Code Postale 